\title{
The use of probiotics in gastrointestinal disease
}

\author{
Karen L Madsen PhD
}

\begin{abstract}
KL Madsen. The use of probiotics in gastrointestinal disease. Can J Gastroenterol 2001;15(12):817-822. Probiotics are living microorganisms that can affect the host in a beneficial manner. Prebiotics are nondigestible food ingredients that stimulate the growth and activity of probiotic bacteria already established in the colon. Efficacy of probiotic compounds has been shown in a wide range of gastrointestinal diseases. Lactobacillus GG alone, or the combination of Bifidobacterium bifidum and Streptococcus thermophilus, is effective in the treatment of Clostridium difficile, as well as in preventing the frequency and severity of infectious acute diarrhea in children. Prevention of antibiotic-induced diarrhea with the concomitant administration of either Lactobacillus GG or Saccharomyces boulardii has been demonstrated. The most successful studies involve the use of Lactobacillus GG at a dose of $1 \times 10^{10}$ viable organisms per day and the yeast boulardii at a dose of $1 \mathrm{~g} /$ day. A probiotic preparation (VSL\#3 $-6 \mathrm{~g} /$ day) that uses a combination of three species of Bifidobacterium, four strains of Lactobacillus and one strain of Streptocccus has shown promise in maintaining remission in ulcerative colitis and pouchitis, as well as in preventing the postoperative recurrence of Crohn's disease. The mechanism of action of probiotics may include receptor competition, effects on mucin secretion or probiotic immunomodulation of gut-associated lymphoid tissue. Oral administration of probiotic compounds has been demonstrated to be well tolerated and safe. However, while probiotics have the potential to improve human health and to prevent and treat some diseases, major improvements are needed in labelling and quality assurance procedures for probiotic compounds. In addition, well planned and controlled clinical studies are necessary to delineate fully the potential for probiotic compounds.
\end{abstract}

Key Words: Bifidobacteria; Diarrhea; Inflammatory bowel disease; Lactobacillus species; Prebiotic; Probiotic

\section{Les probiotiques et les troubles gastro-intestinaux}

RESUME : Les probiotiques sont des micro-organismes vivants susceptibles de produire des effets bénéfiques chez l'hôte. Ce sont des ingrédients alimentaires non digestibles qui stimulent la croissance et l'activité des bactéries probiotiques déjà présentes dans le côlon. Leur efficacité a été prouvée dans de nombreux troubles gastro-intestinaux. Ainsi, Lactobacillus GG, seul ou en association avec Bifidobacterium bifidum ou Streptococcus thermophilus, s'est révélé efficace pour traiter les infections à Clostridium difficile et prévenir la fréquence et la gravité des diarrhées aiguës d'origine infectieuse chez les enfants. De plus, on a montré que l'administration concomitante de Lactobacillus GG ou de Saccharomyces boulardii peut prévenir les diarrhées secondaires à la prise d'antibiotiques. Les essais les plus fructueux font état du recours à Lactobacillus GG administré à raison de $1 \times 10^{10}$ de micro-organismes viables par jour et à la levure Boulardii, à raison de $1 \mathrm{~g} /$ jour. Une préparation probiotique (VSL-3, 6 g/jour) composée de trois espèces de Bifidobacterium, de quatre souches de Lactobacillus et d'une souche de Streptococcus s'est révélée prometteuse pour le maintien de la rémission dans les cas de recto-colite hémorragique et de pochite ou la prévention de la réapparition de la maladie de Crohn après une opération. Parmi les mécanismes d'action possibles figurent la liaison concurrentielle aux récepteurs, les effets sur la sécrétion de mucine ou l'immuno-modulation probiotique du tissu lymphoïde associé à l'intestin. La tolérabilité et l'innocuité de l'administration orale des composés probiotiques ne restent plus à établir. Toutefois, même si les probiotiques peuvent améliorer la santé des humains et prévenir ou traiter certaines maladies, l'étiquetage et les mesures d'assurance de la qualité doivent faire l'objet d'améliorations importantes. En outre, il faudrait mener des essais cliniques comparatifs, bien conçus pour déterminer clairement les effets possibles des probiotiques.
$\mathrm{O}$ ral probiotics are living microorganisms that, upon ingestion, affect the host in a beneficial manner by modulating mucosal and systemic immunity, as well as improving nutritional and microbial balance in the intestinal tract (1). The main probiotic preparations on the market belong to a large group of bacteria designated as lactic

\footnotetext{
University of Alberta, Edmonton, Alberta

Correspondence: Dr Karen L Madsen, University of Alberta, 536 Newton Building, Edmonton, Alberta T6G $2 \mathrm{C} 2$.

Telephone 780-492-5257, fax 780-407-3744, e-mail karen.madsen@ualberta.ca

Received for publication June 19, 2000. Accepted September 6, 2000
} 
TABLE 1

Common probiotics, prebiotics and symbiotics

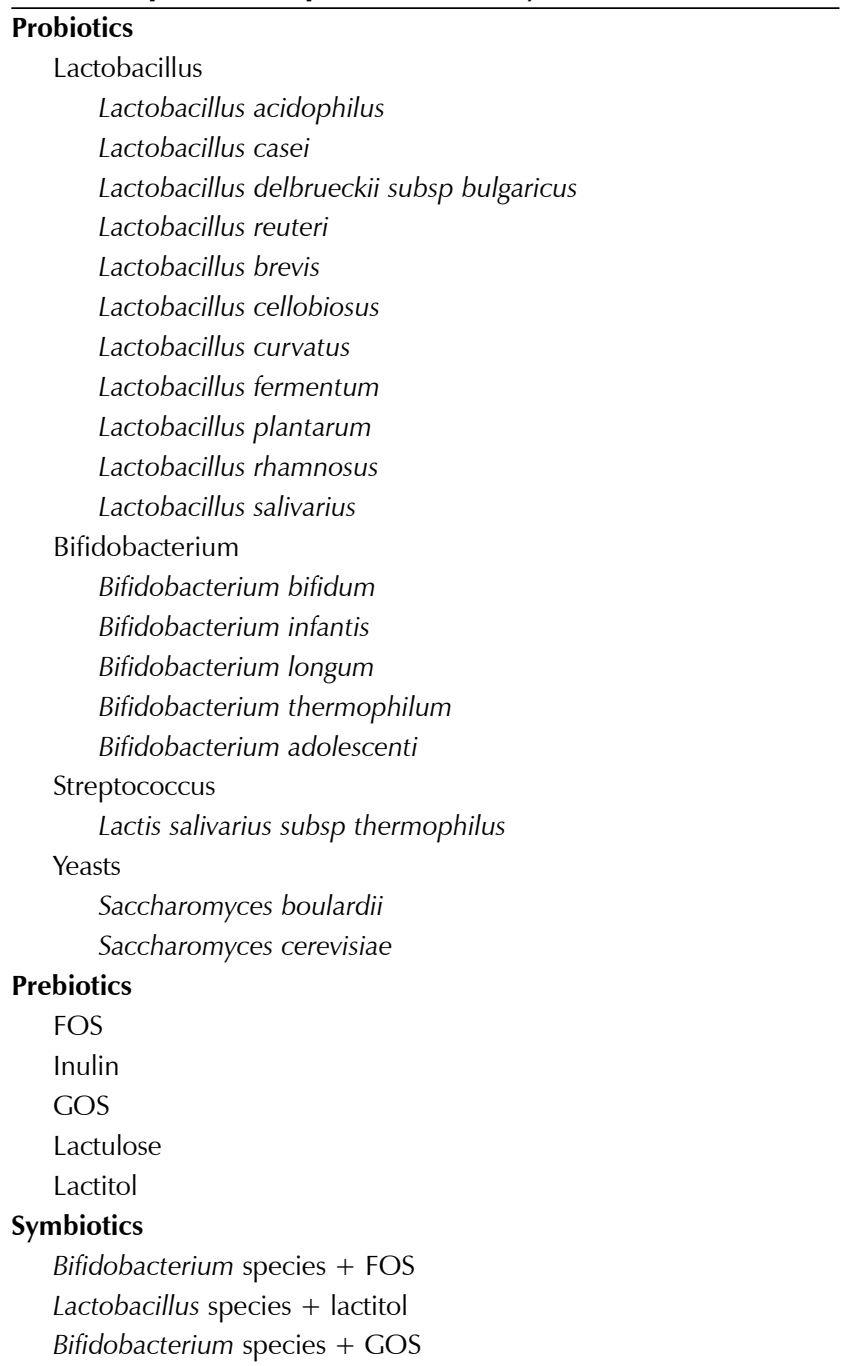

FOS Fructo-oligosaccharides; GOS Galacto-oligosaccharides

acid bacteria (Lactobacillus, Streptococcus, Bifidobacterium species) that are important and normal constituents of the human gastrointestinal microflora (Table 1). However, studies are also investigating the potential probiotic roles of other microbes, such as yeast (Saccharomyces boulardii), which are not normally found in the gastrointestinal tract.

Prebiotics are nondigestible food ingredients that beneficially affect the host by selectively stimulating the growth and/or activity of one, or a limited number of, bacterial species already established in the colon (2). Substances that act as prebiotics cannot be hydrolyzed or absorbed in the upper part of the gastrointestinal tract but are available as substrates for the indigenous bacteria in the colon. Nondigestible oligosaccharides in general, and fructooligosaccharides (FOS) in particular, are prebiotics. These low molecular weight carbohydrates are found naturally in onions, garlic, leeks, chicory, artichokes and some cereals. Other oligosaccharides (raffinose and stachyose) are found in beans and peas. These molecules are also produced indus-
TABLE 2

Alleged health claims for probiotics

\begin{tabular}{ll}
\hline Intestinal disorders & Other disorders \\
\hline Diarrhea & Vaginitis \\
$\quad$ Antibiotic-induced & Alcohol-induced liver disease \\
$\quad$ Traveller's & Cancer prevention \\
$\quad$ Infantile & Hypercholesteremia \\
Constipation & Food allergy \\
Salmonella and Shigella & Prevention of osteoperosis \\
$\quad$ species infections & Cystic fibrosis \\
Inflammatory bowel disease & Cystitis \\
Lactose intolerance & \\
Flatulence & \\
Colon cancer & \\
\hline
\end{tabular}

trially, and a number of new prebiotic preparations are being developed for the market. The beneficial effect of prebiotic intake on the host may result from either suppression of the growth of harmful microorganisms or the stimulation of favourable organisms (mainly Lactobacillus species and Bifidobacterium species). For instance, in controlled dietary studies, intake of FOS (15 g/day) increased fecal Bifidobacterium species numbers 10 -fold, while reducing Clostridia and Enterobacteria counts (3). However, it should be mentioned that intake of FOS at this dose may give some patients significant gastrointestinal symptoms, even apart from alterations in microbial flora.

A symbiotic is a product in which a probiotic and a prebiotic are combined. The rationale for this combination is that survival of the probiotic bacteria is improved during the passage through the upper intestinal tract, implantation in the colon is more efficient, and the prebiotic has a stimulating effect on the growth of both the exogenous (probiotic) and endogenous bacteria.

Recent global marketing trends of probiotics and prebiotics are based on numerous claims of various health benefits that have varying levels of supporting scientific evidence (Table 2). The emergence of microorganisms with acquired antibiotic resistance profiles, and increasing public concern about disease prevention and maintenance of health, are also driving the search for approaches to therapy that do not involve pharmaceutical agents. Thousands of different microbial preparations are available to the public. Traditionally, probiotic strains have been incorporated into fermented milk products, but dietary supplements containing Lactobacillus species, Bifidobacterium bifidum, Streptococcus thermophilus, or a combination of these microorganisms, are now available in capsules, tablets and enteric-coated formulations. However, it must be remembered that there is no substantial regulation in this area; thus, there is no guarantee that an over-the-counter product will contain the bacterial species listed on the label or that the bacteria will be viable. Indeed, a study performed by Hamilton-Miller et al (4) showed that, of 52 probiotic products, very few actually contained what was listed on the label. Often, products contained lower numbers of bacteria than were listed on 
the label, contained extraneous bacterial strains not listed on the label, or did not contain the strains listed on the label. Thus, it is difficult to advise which products to purchase. Although probiotics and prebiotics have been used in humans and animals for centuries, only recently have these formulations been subjected to any type of controlled clinical research. The present review outlines various documented findings on the probiotics and prebiotics, with particular emphasis on gastrointestinal disease.

\section{MICROBIAL ECOLOGY OF THE HUMAN GUT}

It is estimated that more than 400 bacterial species inhabit the human intestinal tract. Among these, only 30 to 40 species constitute some $99 \%$ of the mass of intestinal flora (Figure 1). Although environmental factors and physiological interactions can modulate the distribution of the microflora, diet appears to be the major factor that regulates the frequency and concentration of individual species of microorganisms that colonize the gut.

Bacteria entering the mouth are washed with saliva into the stomach. Most bacteria are destroyed by gastric acid, resulting in a very sparse bacterial population in the upper small bowel because only the most acid-resistant organisms survive transit through the stomach. The small intestine constitutes a zone of transition between the sparsely populated stomach and the luxuriant bacterial flora of the colon. In addition, bile acids, bicarbonate, lactozyme, mucins, peristalsis and antimicrobial peptides all contribute to the relative scarcity of bacterial colonization in the small intestine (5). In the colon, all available habitats are occupied by indigenous microorganisms. At least three major bacterial habitats have been described: the lumen of the gastrointestinal tract, the mucus gel that overlies the epithelium and the adherence of bacteria to receptors on mucosal epithelial cells (6).

One of the major problems that oral probiotics face is how to ensure survival of the microbe during the passage from the mouth to the colon. Indeed, microbial strains used as probiotics must be both acid- and bile-resistant. Whether it is necessary for probiotic bacteria to have the ability to colonize the colon for long term survival is not known. For example, common commercial strains such as Lactobacillus bulgaricus and Lactobacillus acidophilus are not adhesive in humans. However, convincing mucosal adhesiveness has been shown for Lactobacillus plantarum strains 299 and 299V, Lactobacillus rhamnosus strains GG and 271, and recently, $L$ acidophilus strain LA1, Lactobacillus salivarius, and Bifidobacterium longum infantis. It must be remembered that when using preparations of microbes that are unable to adhere to the colonic mucosa, continuous consumption is necessary to maintain any beneficial effects. However, even strains such as L rhamnosus, which does adhere to mucosa, gradually disappear by approximately two weeks after the end of administration of the bacteria (7). However, it must also be noted that adherent probiotics can persist on colonic mucosa even after the strain is no longer detectable in fecal samples (7). Thus, testing for the presence of a pro-

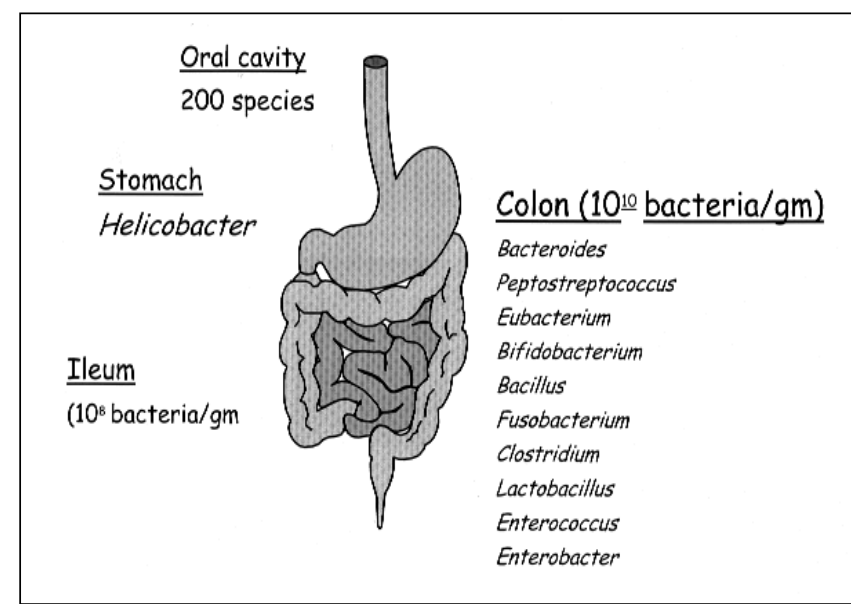

Figure 1) Distribution of bacterial species in the gastrointestinal tract

biotic by testing fecal samples alone may severely underestimate the levels present within the colon.

\section{INTESTINAL DISORDERS}

Gastrointestinal infection: The colonic microflora and epithelial cells normally present barriers to invading organisms, but pathogens can become established when the integrity of either becomes compromised through stress, illness, antibiotic treatment, changes in diet or physiological alterations in the gut. Both Lactobacillus and Bifidobacterium species have been widely used in treating diarrheal diseases such as pseudomembranous colitis, antibiotic-induced diarrhea, traveller's diarrhea and infantile diarrhea, with mixed results. However, this may be due to the use of ineffectual strains of microbes. For instance, feeding freeze-dried powders of $L$ acidophilus had no effect in patients with pseudomembranous colitis (8), but another study using Lactobacillus GG showed a successful eradication of Clostridium difficile in patients with relapsing colitis (9). In a double-blind, placebo controlled trial, Saavedra et al (10) reported that a combination of $B$ bifidum and $S$ thermophilus was an effective prevention strategy to reduce the frequency and severity of acute diarrhea in children. The yeast $S$ boulardii has also been used successfully in the prevention and treatment of diarrhea associated with $\mathrm{C}$ difficile infection (11). Over 50 published clinical studies have examined the impact of probiotics on diarrheal diseases. The most successful studies have involved the use of Lactobacillus GG at a dose of $1 \times 10^{10}$ viable organisms per day and the yeast $S$ boulardii at a dose of $1 \mathrm{~g} /$ day. Overall, the evidence supports the clinical efficacy of Lactobacillus GG and S boulardii in reducing the severity and duration of diarrhea in both viral and bacterial enteritis and enterocolitis.

Traveller's diarrhea: Lactobacillus, Bifidobacterium, Enterococcus and Streptococcus species have been used prophylactically to prevent traveller's diarrhea with limited success. Hilton et al (12) and Black et al (13) both demonstrated a reduction in the risk of traveller's diarrhea with prophylactic use of $L$ rhamnosus or the combination of $S$ thermophilus, 
L bulgaricus, $L$ acidophilus and B bifidum, respectively. Conversely, a well-controlled study on British soldiers failed to show any protective effect of Lactobacillus fermentum or $L$ acidophilus (14). These mixed results may be due to the use of ineffective strains of microbes. Thus, while the concept of protection from traveller's diarrhea using probiotics remains appealing, there are limited data to support this use. Further clinical trials are needed in this area.

Antibiotic-induced diarrhea: The use of antibiotics results in a severe attack on the normal gastrointestinal flora. Probiotics can be used to help the indigenous gastrointestinal flora withstand this assault. Vanderhoof et al (15) evaluated the use of concomitant ingestion of Lactobacillus GG in children who received antibiotics for various acute illnesses. They found that diarrhea occurred in $25 \%$ of children in the placebo group compared with only $8 \%$ in the group that received the probiotic. In addition, the probiotic shortened the duration and severity of the diarrhea. Prevention of antibiotic-associated diarrhea with $S$ boulardii ( $1 \mathrm{~g} /$ day $)$ has also been shown $(16,17)$.

Inflammatory bowel disease: Very recent reports have suggested that probiotics may be beneficial in the maintenance of remission of ulcerative colitis and pouchitis. In a preliminary study, 15 patients with ulcerative colitis who were intolerant to or allergic to 5-acetylsalicylic acid were treated with a new probiotic preparation (VSL\#3 [VSL Pharmaceuticals, United States]) using a combination of three species of Bifidobacterium (B longum, Bifidobacterium breve and $B$ infantis), four strains of Lactobacillus species (Lactobacillus casei, L plantarum, L acidophilus and Lactobacillus delbruekii subsp bulgaricus) and one strain of Streptococcus (Streptococcus salivarius subsp thermophilus) $\left(5 \times 10^{11}\right.$ cells/g/day). In this study, $75 \%$ (12 of 15$)$ of patients remained in remission after 12 months of treatment (18). This clinical response was associated with a significant increase in the fecal concentration of Lactobacillus species, Bifidobacterium species and $S$ thermophilus from day 15 of treatment (18). This preparation has two main innovative characteristics compared with other probiotic compounds - a very high bacterial concentration and the presence of a mixture of different bacterial species that has the potential to have synergistic associations. Further to these studies, a double-blind, randomized trial was carried out to investigate the efficacy of the VSL $\# 3$ preparation in the maintenance treatment of chronic, relapsing pouchitis (19). Forty patients were randomly assigned to receive VSL\#3 (6 g/day) or placebo for nine months (19). All patients had chronic pouchitis (defined as a history of the need for continuing medical suppressive therapy and recurrence within a few weeks of discontinuing suppression) and were in remission (Pouchitis Disease Activity Index [PDAI] score of zero after open induction of remission therapy with antibiotics). Relapse was defined as an increase of two or more points in the clinical portion of PDAI. Clinical assessment and stool culture were done monthly, while endoscopic and histological assessment were done every two months. At the end of the study period, 17 of the 20 patients treated with VSL $\# 3$ remained in remission compared with zero of 20 in the placebo arm (19). Fecal concentration of Lactobacillus, Bifidobacterium and $S$ thermophilus increased only in the VSL\#3 group and remained stable for the entire nine months of treatment. One month after stopping probiotic treatment, fecal concentrations of these bacterial species returned to baseline. Within four months of removing active therapy, $100 \%$ of the responding patients had relapsed. No toxicity or adverse effects of this treatment were observed. Whether all of these bacterial species are necessary for the VSL\#3 effects is unknown and remains to be shown. Indeed, a small study examining the ability of Lactobacillus GG alone, albeit combined with FOS, to treat refractory pouchitis showed efficacy in reversing macroscopic endoscopic alterations (20).

While the above studies validate the clinical efficacy of the VSL\#3 compound in maintenance therapy of some inflammatory bowel diseases, previous human trials of other probiotic compounds have produced less convincing results. For example, while Rembacken et al (21) demonstrated that a nonpathogenic strain of Escherichia coli (serotype 06:D5:H1), two capsules twice daily $\left(2.5 \times 10^{10}\right.$ viable bacteria per capsule), was as effective as mesalazine ( 1.4 to $2.4 \mathrm{~g} /$ day) in maintaining remission in patients with ulcerative colitis, this study had several flaws (22). The patient group was heterogeneous with regard to the severity of the illness (mild to severe), and patients were treated with several different corticosteroid formulations as well as the study medication. Also, the doses of mesalazine used were relatively low, and only a very small number of patients remained in remission at the end of the study.

$S$ boulardii, in combination with mesalamine, has recently been shown to be more effective than mesalamine alone in the maintenance treatment of inactive Crohn's disease (23), and a combination of antibiotic and probiotic treatment using the VSL\#3 compound was shown to be more effective than mesalamine in the prevention of postoperative recurrence of Crohn's disease (24). These findings indicate that probiotics could represent a form of maintenance treatment for inflammatory bowel diseases.

Prevention of colon cancer: The consumption of probiotics and/or prebiotics may have several antimutagenic effects, including the inhibition of mutagenic activity, a decrease in enzymes implicated in the generation of carcinogens and the suppression of tumours (25). For instance, lactic acid bacteria bind mutagenic pyrolysates produced during cooking at high temperatures as well as degrading carcinogens such as $\mathrm{N}$-nitrosamines. Indeed, the link between high fat/low fibre Western-style diets and a higher risk of colon cancer can partially be explained by the alterations in fecal bacterial enzyme activity induced by a Western-style diet. Fecal bacterial beta-glucuronidase, nitroreductase, azoreductase and steroid 7-alpha-dehydroxylase have been implicated in the conversion of precarcinogens into carcinogens within the colonic lumen; furthermore, these enzymes are all increased in the colons of those consuming a high fat/low fibre diet. Tumour sup- 
pression by probiotics has been shown to exist in numerous animal models and the biological basis of the suppression attributed to either diminished neoplastic enzyme activity or immunostimulation of the host. However, there is not yet any direct evidence that probiotics can protect against the development of colon cancer.

Lactose intolerance: There is evidence to suggest that probiotics may have some use in the treatment of patients with lactase deficiency (26). During fermentation, lactic acid bacteria, especially $L$ bulgaricus, produce lactase, which hydrolyzes the lactose in dairy products to glucose and galactose (26). It has been shown that lactose is better digested from yogurt than from milk by lactase-deficient individuals; furthermore, yogurt intake in these patients is paralleled by reduced symptoms (26). This effect of yogurt appears to be related to a high enzymatic content of betagalactosidase (27).

\section{MECHANISM OF ACTION OF PROBOTICS}

The probiotic approach to the treatment of gastrointestinal disease remains controversial and will remain so until the mechanisms through which probiotic bacterial strains antagonize pathogenic organisms or exert other beneficial effects in the host are fully understood through wellplanned scientific study. Furthermore, there are significant differences between probiotic bacterial genera and species. It is crucial that each strain be tested on its own or in products designed for a specific function. Much research is directed toward understanding the mechanisms of action of oral probiotics. The main areas being examined are receptor competition, whereby probiotics compete with microbial pathogens for a limited number of receptors present on the surface epithelium; probiotic release of antimicrobial compounds (28); probiotic-induced increased levels of mucin secretion, which acts to block pathogen binding to epithelial receptors (29); probiotic bacterial 'priming' of gut-associated lymphoid tissue; and immunomodulation of gut-associated lymphoid and epithelial tissue response (30-32). Probiotics are able to enhance the activity of the intestinal immune system through the stimulation of macrophage and natural killer cells, the proliferation of lymphocytes and the increase of secretory immunoglobulin A production (33), although the specificity of the secretory immunoglobulin $\mathrm{A}$ production was unknown. Selected strains of probiotics are able to alter mucosal and systemic immune function at many levels, including stimulating mucosal production of interleukin-10 (34) and producing systemic $\mathrm{T}$ helper 2 reponses (31). However, it remains to be proven which, if any, of these mechanisms have a clinical benefit or how they alter the pathophysiology of gastrointestinal diseases. With regard to the pathophysiology of inflammatory bowel disease, one of the most widely accepted theories is that the inflammation results from a dysregulation of the immune system to normal gut flora. Thus, common probiotic species may contribute to chronic inflammation. However, in several animal models, not all gut microflora cause the same degree of inflammation (35). Indeed, there are several reports demonstrating that probiotic species tend to downregulate pro-inflammatory cytokine release rather than stimulate secretion (30-32). Thus, while it is possible that some probiotic strains may contribute to chronic inflammation, some of the strains may actively suppress inflammation.

Once protective mechanisms are understood, it will be possible to identify bacterial species as possessing certain beneficial traits, and optimal doses, timing of administration and potential synergy between bacterial species can then be determined. Several studies have shown that concentrations of endogenous Lactobacillus and Bifidobacterium species are decreased during active Crohn's disease, ulcerative colitis and pouchitis (36). Leading from these findings is the speculation that the ratio of protective to harmful luminal bacteria may be involved in the determination of mucosal homeostasis, and that restoring microbial balance through antibiotic, probiotic and prebiotic approaches may be a true physiological approach to the treatment of gastrointestinal disease (37).

\section{SAFETY AND TOLERANCE}

Oral administration of probiotic compounds has been demonstrated to be well tolerated and proven to be safe in 143 human clinical trials occurring between 1961 and 1999. No adverse effects or events were reported in any of the 7526 subjects participating in these trials. However, rare cases of local or systemic infections, including septicemia and endocarditis due to Lactobacillus, have been reported $(38,39)$. These infections have occurred in immunocompromised patients with aplasia (40), organ transplantation (41) and human immunodeficiency virus infection $(42,43)$. In most of these cases, the source of the infection was the commensal Lactobacillus flora, rather than an ingested bacteria supplement, suggesting that these bacteria can act as opportunistic pathogens. With regard to Saccharomyces infections, there have been few reports of fungemia due to Saccharomyces species, again, usually in immunocompromised patients receiving high enteral doses of Ultra-Levure (Biocodex, Montrouge, France) containing S boulardii (1.5 g/day) (44). Although rare, these reports suggest that caution and further studies are necessary to assess the safety of probiotic bacteria for immunodeficient hosts.

\section{CONCLUSIONS}

Probiotics have the potential to improve human health, and to prevent and treat a wide variety of diseases. Results from human clinical trials and scientific studies have confirmed the preventive and therapeutic effects of selected strains of microbes in viral and bacterial intestinal infections, and in positively influencing immunological parameters. However, several of these documented results need more rigorous research to be confirmed (45). Furthermore, it must be remembered that not all Lactobacillus or Bifidobacterium species are equal, and not all over-thecounter products contain the bacterial species listed on the label or, indeed, any viable bacteria at all. Thus, until major 
improvements occur in the regulation of labelling and quality assurance procedures for probiotic compounds, it is difficult to recommend which products to purchase. In addition, more adequately designed and properly executed clinical trials are necessary to carefully explore and characterize the therapeutic applications of probiotics.

ACKNOWLEDGEMENTS: Dr Madsen is supported as an Alberta Heritage Foundation for Medical Research scholar, Crohn's and Colitis Foundation of Canada.

\section{REFERENCES}

1. Fuller R. Probiotics in man and animals. J Appl Bacteriol 1989;66:365-78.

2. Gibson G, Roberfroid MB. Dietary modulation of the human colonic microbiotia: introducing the concept of prebiotics. J Nutr 1995; 125:1401-12.

3. Hayakawa K, Mizutani J, Wada K, Masai T, Yoshihara I Mitsuoka T. Effects of soybean oligosaccharides on human faecal microflora. Microb Ecol Health Dis 1990;3:293-303.

4. Hamilton-Miller JM, Shah S, Winkler JT. Public health issues arising from microbiological and labelling quality of foods and supplements containing probiotic microorganisms. Public Health Nutr 1999;2:223-9.

5. Huttner KM, Bevins CL. Antimicrobial peptides as mediators of epithelial host defense. Pediatr Res 1999;45:785-94.

6. Berg RD. The indigenous gastrointestinal microflora. Trends Microbiol 1996;433:430-5.

7. Alander M, Satokari R, Korpela R, et al. Persistence of colonization of human colonic mucosa by a probiotic strain, Lactobacillus rhamnosus GG, after oral consumption. Appl Environ Microbiol 1999;65:351-4.

8. Aronsson B, Barany P, Nord CE. Clostridium difficile-associated diarrhoea in uremic patients. Eur J Clin Microbiol 1987;6:352-6.

9. Gorbach SI, Chang T, Goldin B. Successful treatment of relapsing Clostridium difficile colitis with Lactobacillus GG. Lancet 1987;ii: 1519.

10. Saavedra JM, Abi-Hanna A. Clinical studies of probiotic agents. In: Hanson L, Yolken RH, eds. Probiotics. Other Nutritional Factors, and Intestinal Microflora. Philadelphia: Lippincott-Raven, 1999:271-86.

11. McFarland LV, Surawicz CM, Greenberg RN, et al. A randomized placebo-controlled trial of Saccharomyces boulardii in combination with standard antibiotics for Clostridium difficile disease. JAMA 1994;271:1913-8.

12. Hilton E, Kolakowski P, Singer C, et al. Efficacy of Lactobacillus GG as a diarrheal preventive in travellers. J Travel Med 1997;4:41-3.

13. Black FT, Andersen PI, Orskov J, Orskov F, Gaarslev K, Laulund S. Prophylactic efficacy of lactobacilli on traveller's diarrhea. In: Steffen R, ed. Travel Medicine. Conference on International Travel Medicine 1, Zurich, Switzerland. Berlin: Springer, 1989:333-5.

14. Katelaris PH, Salam I, Farthing MJ. Lactobacilli to prevent travellers's diarrhea? N Engl J Med 1995;330:1360-1.

15. Vanderhoof JA, Whitney DB, Antonson KL, Hanner TL, Lupo JB, Young RJ. Lactobacillus GG in the prevention of antibiotic-associated diarrhea in children. J Pediatr 1999;135:564-8.

16. McFarland LV, Surawicz CM, Greenberg RN, et al. Prevention of beta-lactam-associated diarrhea by Saccharomyces boulardii compared with placebo. Am J Gastroenterol 1995;90:439-48.

17. Surawicz CM, Elmer G, Speelman P, Lynn V, McFarland LV, Chinned J. Prevention of antibiotic-associated diarrhea by Saccharomyces boulardii: a prospective study. Gastroenterology 1989;9:981-8.

18. Venturi A, Gionchetti P, Rixxello F, et al. Impact on the composition of the faecal flora by a new probiotic preparation: preliminary data on maintenance treatment of patients with ulcerative colitis. Aliment Pharmacol Ther 1999:13:1103-8.

19. Gionchetti P, Rizzello F, Venturi A, et al. Oral bacteriotherapy as maintenance treatment in patients with chronic pouchitis: a doubleblind, placebo-controlled trial. Gastroenterolgy 2000;119:305-9.

20. Friedman G, George J. Treatment of refractory pouchitis with prebiotic and probiotic therapy. Gastroenterology 2000;118:A4167.

21. Rembacken BJ, Snelling AM, Hawkey PM, Chalmers DM, Axon AT.
Non-pathogenic Escherichia coli versus mesalazine for the treatment of ulcerative colitis: a randomised trial. Lancet 1999;354:635-9.

22. Faubion WA, Sandborn WJ. Probiotic therapy with E. coli for ulcerative colitis: Take the good with the bad. Gastroenterology 2000;118:630-5.

23. Guslandi M, Mezzi G, Sorghi M, Testoni PA. Saccharomyces boulardii in maintenance treatment of Chrohn's disease. Dig Dis Sci 2000;45:1462-4.

24. Campieri M, Rizzello F, Venturi A, et al. Combination of antibiotic and probiotic treatment is efficacious in prophylaxis of post-operative recurrence of Crohn's disease: a randomized controlled study vs mesalamine. Gastroenterology 2000;118:A4179. (Abst)

25. Naidu ASS, Bidlack R, Clemens RA. Probiotic spectra of lactic acid bacteria. Crit Rev Food Sci Nutr 1999:38:13-126.

26. Marteau P, Vesa T, Rambaud JC. Lactose maldigestion. In: Fuller R, ed. Probiotics 2. Applications and Practical Aspects. London: Chapman and Hall, 1997:65-88.

27. Salminen S, Deighton MA, Benno Y, Gorbach SL. Lactic acid bacteria in health and disease. In: Salminen S, von Wright A, eds. Lactic Acid Bacteria. Microbiology and Functional Aspects. New York: Marcel Dekker, 1998:211-53.

28. Ahn C, Stiles ME. Antibacterial activity of lactic acid bacteria isolated from vacuum-packed meats. J Appl Bacteriol 1990;69:302-10.

29. Mack DR, Michael S, Wei S, McDougall L, Hollingsworth MA. Probiotics inhibit enteropathogenic E. coli adherence in vitro by inducing intestinal mucin gene expression. Am J Physiol 1999;276:G941-50.

30. Neish AS, Gewirtz AT, Zeng H, et al. Prokaryotic regulation of epithelial responses by inhibition of IkappaB-alpha ubiquitination. Science 2000;289:1560-3.

31. Schultz M, Linde H, Staudner H, Lehn N, Falk W, Schoelmerich J. Oral administration of Lactobacillus GG induces an anti-inflammatory, Th-2 mediated systemic immune response towards intestinal organisms. Gastroenterology 2000;118:A4180. (Abst)

32. O'Mahony L, Feeney M, MacSharry J, et al. Probiotics, mononuclear cells, and epithelial cells: an anti-inflammatory network. Gastroenterology 2000;118:A680. (Abst)

33. Malin M, Suomalainen H, Saxelin M, Isolauri E. Promotion of IgA immune response in patients with Crohn's disease by oral bacteriotherapy with Lactobacillus GG. Ann Nutr Metab 1996;40:137-45.

34. Helwig U, Rizzello F, Cifone G, et al. Elevated IL-10 levels in pouchtissue after probiotic therapy. Immunol Lett 1999;69:159.

35. Rath HC, Wilson KH, Sartor RB. Differential induction of colitis and gastritis in HLA-B27 transgenic rats selectively colonized with Bacteroides vulgatus or Esherichia coli. Infect Immun 1999;67:2969-74.

36. Sartor RB. Microbial factors in the pathogenesis of Crohn's disease, ulcerative colitis, and experimental intestinal inflammation. In: Kirsner JB, ed. Inflammatory Bowel Diseases. 5th edn. Philadelphia: Saunders, 1999:153-78.

37. Sartor RB. Probiotics in chronic pouchitis: restoring luminal microbial balance. Gastroenterolgoy 2000;119:584-5.

38. Griffiths JK, Daly JS, Dodge RA. Two cases of endocarditis due to Lactobacillus species, antimicrobial susceptibility, review and discussion of therapy. Clin Infect Dis 1992;15:250-5.

39. Antony SJ, Stratton CW, Dummer JS. Lactobacillus bacteremia, description of the clinical course in adult patients without endocarditis. Clin Infect Dis 1996;23:773-8.

40. Chomarat M, Espinouse D. Lactobacillus rhamnosus septicemia in patients with prolonged aplasia receiving ceftazidimevancomycin. Eur J Clin Microbiol Infect Dis 1991;10:44.

41. Patel R, Cockerill FR, Porayko MK, Osmon DR, Ilstrup DM, Keating MR. Lactobacillemia in liver transplant patients. Clin Infect Dis 1994;18:207-12.

42. Horwitch CA, Furseth HA, Larson AM, Jones TL, Ollife JF, Spach DH. Lactobacillemia in three patients with AIDS. Clin Infec Dis 1995;21:1460-2.

43. Schlegel L, Lemerle S, Geslin P. Lactobacillus species as opportunistic pathogens in immunocompromised patients. Eur J Clin Microbiol Infect Dis 1998;17:887-8.

44. Niault M, Thomas F, Prost J, Ansari FH, Kalfon P. Fungemia due to Saccharomyces species in a patient treated with enteral Saccharomyces boulardii. Clin Infect Dis 1999;28:930.

45. Goldin BR. Health benefits of probiotics. Br J Nutr 1998;80:S203-7. 


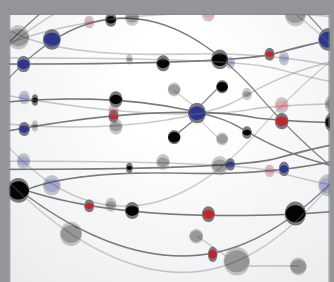

The Scientific World Journal
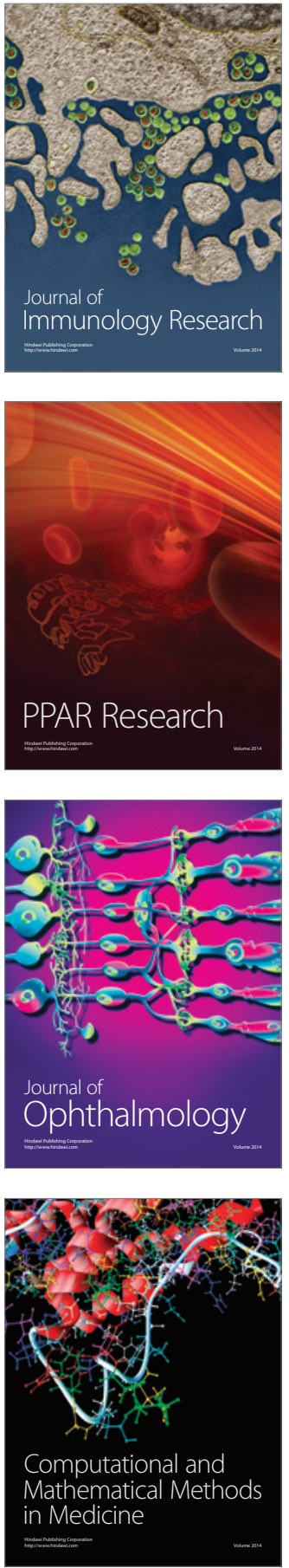

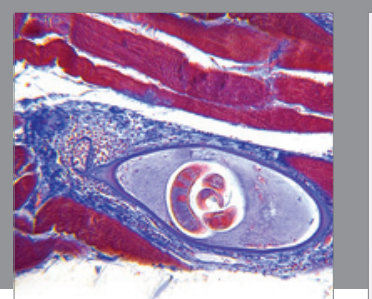

Gastroenterology Research and Practice

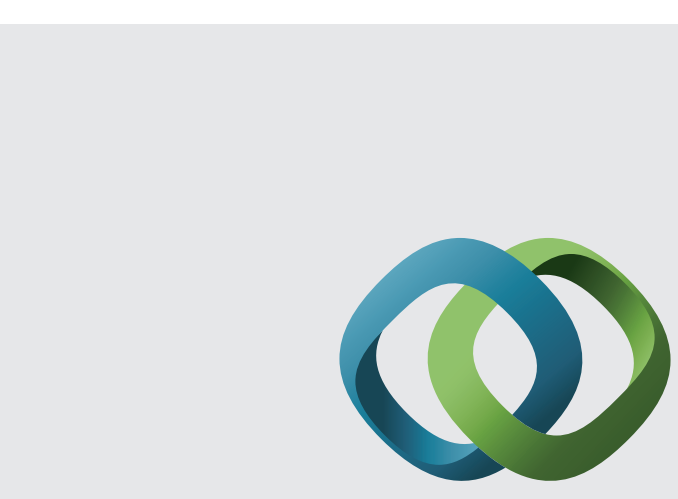

\section{Hindawi}

Submit your manuscripts at

http://www.hindawi.com
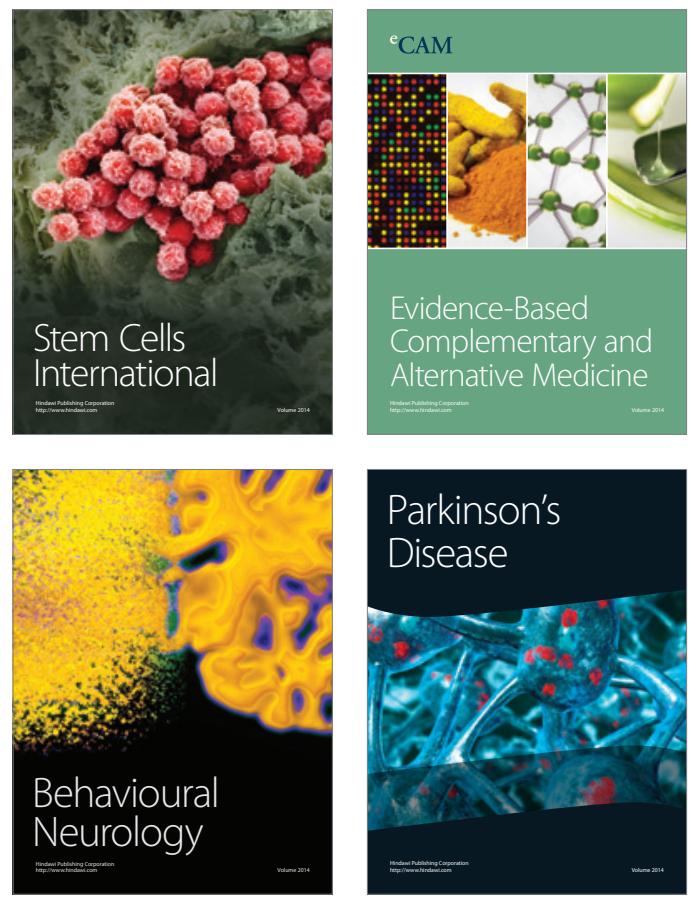
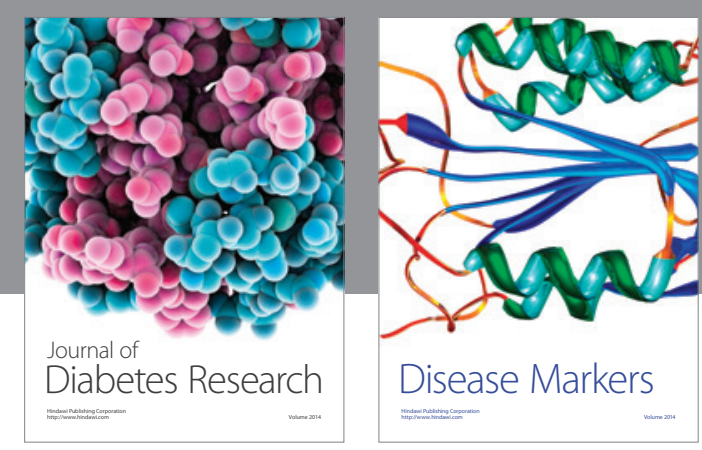

Disease Markers
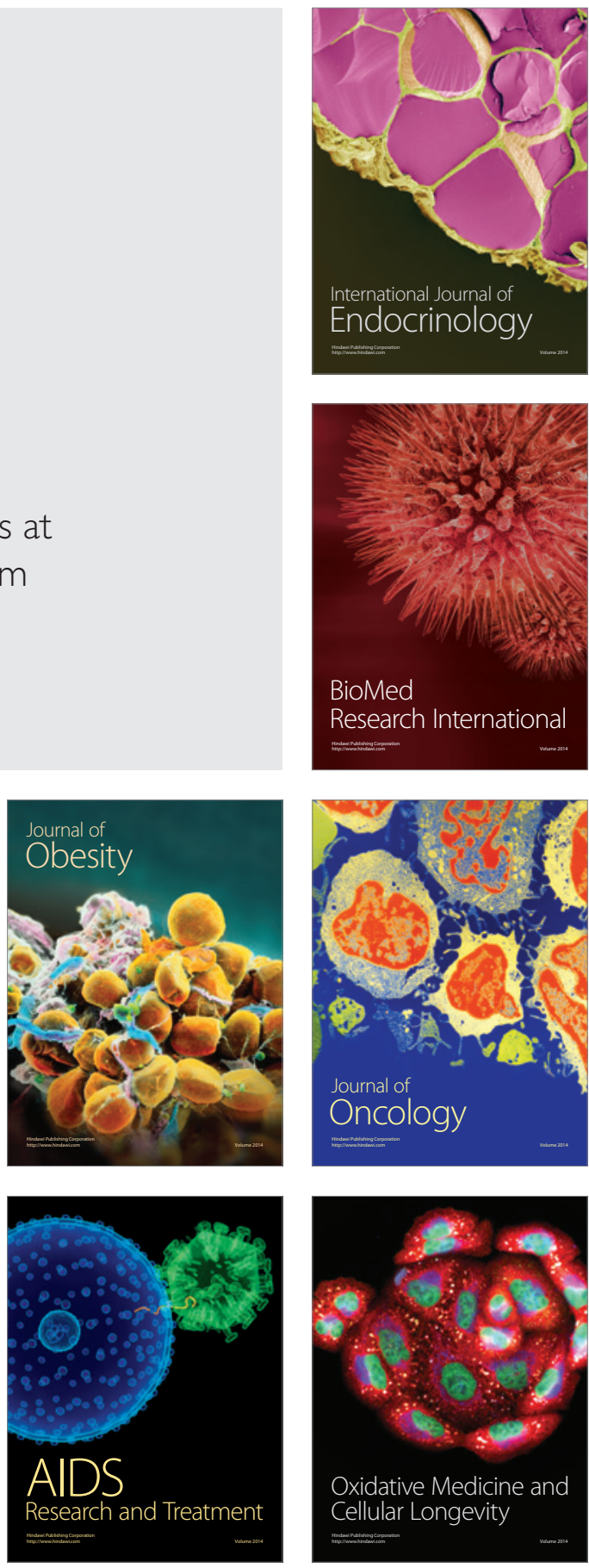